\title{
A Study on the Team Construction of College Student Leaders
}

\section{Sen LIN}

School of Information Science and Engineering, Wuhan University of Science and Technology, Wuhan, China

\begin{abstract}
Student leaders are a special community in college students. They are students who receive college education and hold some managerial post of at the same time. Student leaders, as the right-hand men to implement activities, play a special role in the student management, teaching and establishing campus culture. It's one of the significant tasks for student work to construct a group of student leaders equipped with high quality and strong ability. This article will start from strengthening the construction of student leaders, and put forward the thought of the construction of student leaders, like strengthening political-ideological education, selecting student leader scientifically and reasonably, enhancing the training of student leaders and assessing student leaders scientifically.
\end{abstract}

KEYWORD: College; Student leaders; The team construction

College student leader, as a unique group in college students, play an significant part in college management work. Not only are they the bond between college and students, but also the leading role in good construction of study style on campus, main organizers and participants in all kinds of student work. They play an irreplaceable part in the construction of campus culture, college spirit and administration, being the indispensable power to promote the normal function of college student work. In this background, it's pretty necessary to go into the construction of student leaders. Only when sparing every effort to implement this matter can we make further progress in the management of college student.

\section{STRENGTHEN POLITICAL-IDEOLOGICAL EDUCATION TO IMPROVE STUDENT LEADERS' MORAL ATTAINMENTS}

Nowadays, the main stream of ideology and politics of college students is positive and healthy. They love the Party, love our motherland and our socialism, strongly support the principles and policies of the Party, and highly identify the theory of Deng Xiaoping and the important thought of Scientific Outlook on Development, place complete reliance on the Party Central Committee which is under the leadership of Xi Jinping, the General Secretary of CPC. They have faith in following the path of socialism with Chinese characteristics and accomplishing the grand aim of building well-off society in an all-around way. However, due to the great changes in both international and domestic situation, the ideological and political education of college students faces advantages and severe challenges at the same time. The work of ideological and political education of college students hasn't completely adapted to the brand new situation, thus leaving many vulnerable spots. Therefore, enhancing and improving ideological and political education of college students is an extremely urgent task. Serving as college students and the models and leading roles in campus activities, student leaders have to establish correct outlook on the world, life and value, keep on cultivating themselves and creating healthy and positive self-image. To enhance the construction of student leader, the focus should be on the all-round development, the quality education, the harmonious development of ideological and moral cultivation, cultural and scientific qualities, physical constitution, creative ability, and willingness to devote.

\section{ENHANCE THE EFFICIENT MANAGEMENT, AND SELECT THE STUDENT LEADER SCIENTIFICALLY AND REASONABLY.}

Student leader in college is a specific group. The key problem is how to select and appoint them 
reasonably. It is the precondition and foundation to discover able people and put them at suitable posts in the initial selection, which determines whether student leaders in the future work have the combat effectiveness, cohesion, and the ability of communication and coordination between the school and students.

\subsection{Stick to principles}

We should fully grasp the gist of the file issued by The CPC Central Committee and State Council on further enhancing and improving ideological and political education of college. It says that student leader should be qualified with high ideological and moral cultivation. Therefore, it's necessary to select students qualified with high political integrity, strong sense of principles, desire to make progress, strong sense of group honor and healthy psychology into the team of student leaders.

\subsection{Set standards}

As the saying has it, "Nothing can be accomplished without norms or standards." by setting some standards and rules, we teachers have the sound document to abide by and trace back; by setting a series of standards about ideological, psychological quality and productive capacity, student leaders can check themselves, such standards as being qualified with high ideological quality, having deep love for student work, having the spirit of devotion and strong sense of responsibility; being qualified with the ability of comprehensive writing, oral expression and communication and coordination; having relative higher big-picture thinking, better decisionmaking capacity and strong team spirit. Similarly, different standards can be set depending on the different needs of student organizations and positions. For example, the Department of Art and Sports requires members love art activities and sports activities, calls for innovative thoughts to enrich the campus life; the Propagation Department requires calligraphy and painting ability, and also some proficient writing skills and art designing skills.

\subsection{Investigate flexibly}

"Student leaders are usually selected through three stages: students' application, public election, and democratic vote, which is to some extent supposed to be just, fair, democratic and reasonable. However, this approach has a few limitations because it only scratches the surface. To know the candidates thoroughly, it requires multi-faceted understanding and investigation; hence it is necessary to solicit opinions from the institute leaders, the head teachers, instructors, course teachers, other student leaders and ordinary students. Only in this way can we have deeper understanding of all respects of the candidates"[1](p36).

\subsection{Enlist according to the merits}

It is complicated and time-consuming but profitable to select student leaders by combining the result of democratic vote and extensive investigation, getting the best out of someone, valuing people who have talents. Firstly, we can guarantee our student leader qualified with favorable basic quality, professional ability, and willingness to serve others. Secondly, in view of self-recommendation, the selected student leaders have full passion for work and spirit of devotion to serve students. In addition, after soliciting opinions from teachers and normal students, the chosen student leaders have better folk basis and higher prestige, which will contribute to carrying out the activities smoothly. Lastly, through open party line ballot system, student leaders' capacity can be tempered and their sense of competition can be enhanced, which helps them better adapt to the society.

Selecting student leader requires us to keep on discovering, excavating and training the outstanding leaders among students, especially among the freshmen. It is not merely enough to decide the student leader by reading their documents but by observing and discovering the prospective students in various activities, and then providing them with opportunities to improve themselves, which paves the way for the effective selection of student leaders.

\section{ENHANCE THE GUIDANCE IN ALL RESPECTS AND CARRY OUT BETTER TRAINING FOR STUDENT LEADER}

College is the main position to train aspiring, moral, literate, self-disciplined talents for the construction of socialist, thus the training for student leaders, a vital part of those talents, is quite necessary. These strictly selected students don't necessarily make quick adjustment to the brand new positions for lack of experience; nonetheless, an overall training enables them to know the organization and responsibilities of student leaders, and endow them with vitality, motivation, capability and boldness. Imparting some advanced and scientific working methods helps them well handle the relationship between student leaders and ordinary students as well as that between students and college. Besides, illustrating some past problems and consequences help these student leaders avoid similar occurrence in the future. For example, some student leaders shirked responsibility when faced with difficulties while actively seeking out a bonus; some lacked initiative in their work, leading to unsteady 
performance; some easily affected by personal emotions failed to focus on their work; some were unable to balance between study and work, devoting too much energy to work and too little time in study that results in penny- pinching ending.

Great importance should also be attached to the aim of training. After training, student leaders are expected to think positively, study automatically and skillfully, make clear plans and goals, and solve problems adeptly in their work. The above listed abilities help accomplish all kinds of tasks. Besides, they are expected to review after finishing every task, and summarize experience and lesson in order to go further.

\section{DEVELOP EVALUATION SYSTEM TO IMPROVE THE EXECUTIVE FORCE OF THE STUDENT LEADERS}

Whatever work you do, the executive force matters a lot. The freshmen, having not realized the difference in the way of management between secondary schools and colleges which means more space in working, independent thinking, making and finishing plans, can't adapt to the environment and rely on the guidance from teachers. Some student leaders tend to wait for teachers' instructions, thereby resulting in procrastination. Moreover, on account of extremely complex and heavy tasks from work and huge pressure from study, quite a few student leaders may sneak away at a critical juncture and give up halfway for not tolerating so much frustration and pressure. All of the above circumstances will affect the executive force of student leaders. As time passes, the student leader may lose the reputation among students, making it difficult to carry out work, and setting up a vicious circle ultimately.

The president of Hisense once said, "No executive force means no competitiveness." Similarly, no competitiveness means no executive force. How to encourage the student leader to brave various difficulties, address problems and assist teachers in work and set excellent models among students requires the establishment of a reasonable and sound assessment system.

"The final assessment in each semester can well demonstrate the performance and capability of student leaders. The examination and evaluation is an urge and encouragement for student leaders. Praise should be given to those who did their jobs well; guidance and encouragement should be given to those who hadn't dealt with part of their work well enough so they can be aware of their shortcomings and correct them in time. The form of examination and evaluation can be multitudinous and comprehensive. It should be based on teachers, students and self-evaluation. Evaluation is a strategy to improve the executive force of student leaders, make the work carry out smoothly. Instead of evaluating for the sake of evaluation, the examination and evaluation system should make a real difference"[2](p48).

A college is like a machine. The group of student leaders plays an irreplaceable role in the efficient functioning of a college. The effective construction of student leader group serves as the catalyst. By improving student leaders' quality, enhancing their work ability by improving methods of working can we better cooperate with the college's overall work, be consistent with college, promote the management work of students in college, and create a brand new situation of student work.

\section{REFERENCES}

[1] Mai Shouqing. "Study on the construction of the cadre team of college students in the new period". Social Science, 2009, (12).

[2] Jiang Li. "Problems and Countermeasures in the management of university student cadres" Cooperation of economy and technology, 2009, (3). 